\title{
Religious Ecstasy in Classical Sufism
}

\author{
By GÖRAN OGÉN
}

The purpose of this essay is to shed some light on the phenomenon of religious ecstasy as met with in Islamic mysticism and there particularly during its classical period; by the expression "classical Sufism" I do not intend to imply any evaluation but use the phrase solely as a term of convenience to cover the period of Sufi history from about 850 A.D. until circa 1100 A.D. (cf. Meier 1971, 551 and 567 sq.), that is, until the incipient upsurge of the conventual orders.

I have only been able to find one previous independent study of religious ecstasy in Islamic mysticism (Gardet 1950). ${ }^{1}$ But since this study is based primarily on secondary material about the ecstasy of the Sufis, ${ }^{2}$ it does not succeed in conveying to the reader any "inside" information from the Sufi ecstatic's world of experience.

This is, therefore, a particularly stimulating task, although it is not without some hesitation that I commit myself to it, for-as Tor Andræ has pointed out in his sympathetic study of some central features in the spiritual climate of early Islamic mysticism - "the Sufi mystics are particularly reticent in their descriptions of ecstasy and offer only brief hints about the wonderful things they have beheld and experienced in the moments of rapture" (Andræ 1981, 132/1980, 106).

Fortunately some new material has been discovered whilst other material has been made more accessible since Andræ's study was published thirtyfive years ago, followed by Gardet's account three years later. In addition, I am particularly favoured in being able to use a unique little treatise-unique both in its contents, concerning the experiential world of the ecstatic, and in its circulation, for it is hitherto only known to have been preserved in one manuscript; but more of this unique document humain later.

\footnotetext{
1 The material amassed by Ernst Arbman on Sufi ecstasy in volume two (Arbman 1968, 480-515) of his opulent three-volume work Ecstasy or Religious Trance in the Experience of the Ecstatics and from the Psychological Point of View is too hastily and inclusively adopted from translations and secondary literature by European orientalists to be regarded as an independent study of Sufi ecstasy.
}

${ }^{2}$ It consists chiefly of a translation of a chapter entitled "Wagd" ("Ecstasy") in the well-known Sufi manual Kitäb at-ta'arruf by al-Kalābādĩ (d. 995) (Al-Kalābādī ed. 1934, 82-83) and of a translation of a poem by alHallāğ (d. 922) (Al-Hallāğ ed. 1931, 54-55). It is largely on this paper by Louis Gardet that the chapter "Extase" in Anawati-Gardet (1960) and Gardet's article in Dictionnaire de Spiritualité (Gardet 1961) are based. 
Firstly, some reflections on the concept of "religious ecstasy" in general. What is meant by "religious ecstasy" as a concept in Religionswissen$s c h a f t$ ? I myself felt the necessity of establishing a certain clarity about the scope of "religious ecstasy" before plunging into the study of the texts, especially since the Greek word ékstăsis is not to be found in the Arabic word hoard, neither by itself nor in any translated equivalent. Had that been the case, such a linguistic correspondence might then in the Sufi texts have functioned as a first signal of the presence of the phenomenon, which is the case with many other Sufi mystic categories which, via Syriac, often derive from Greek. ${ }^{3}$

To judge from the literature of Religionswissenschaft, the concept of "religious ecstasy" does not seem to have undergone any more exhaustive analysis of meaning or historical description of contents, ${ }^{4}$ a fact which might suggest the existence of a consensus regarding the meaning of this concept. It is also possible, however, that such an analysis of meaning and description of contents will prove necessary when the summary of this symposium is to be made and an inventory of the contents of "religious ecstasy" becomes relevant.

In expectancy of such an inventory, I have contented myself with discovering how this concept is actually used in the general handbookliterature of Religionswissenschaft. For this purpose I have chosen to consult some representative encyclopedias in the field. ${ }^{5}$ All these works, with a span of some sixty years, are largely unanimous in their descriptions of what is characteristic of religious ecstasy. These descriptions may be summed up under the following four points:

1. Ecstasy denotes a state in which the ecstatic is aware of being outside himself (RGG; DCR; DS), or in an abnormal state of consciousness (ERE;

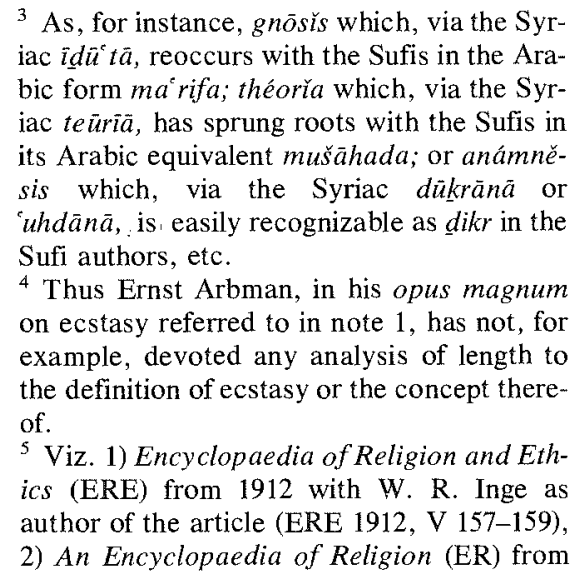

1945 with R. W. Frank as author of the article (ER 1945, 243), 3) Die Religion in Geschichte und Gegenwart (RGG) from 1958 with A. Schimmel as author of the article (RGG 1958, II 410-412), 4) A Dictionary of Comparative Religion (DCR) from 1970 with S. G. F. Brandon as author of the article (DCR 1970, 253). I have also compared with 5) The $O x$ ford Dictionary of the Christian Church (ODCC) from 1958 with an unsigned article (ODCC 1958, 437) and with 6) Dictionnaire de Spiritualité (DS) from 1961 with H. Gratton and O. Leroy as authors of articles (DS 1961, IV 2171-2186) since these more theologically oriented encyclopedias also include common material from Religionswissenschaft. 
ER; ODCC)—that is, what recent psychology classifies as Out-of-BodyExperiences (Grof 1976, 186 sqq.) and generally as Altered States of Consciousness (Ornstein 1977, 81 sq.).

2. Ecstasy produces a changed or inhibited reaction to external stimuli (ERE; ER; RGG; DCR; ODCC; DS), inability to experience pain (ERE), passivity along with an intensive joy (ER), a drop in breathing and circulation to a minimum whereby the ecstatic state may exhibit an external resemblance to sleep (RGG); uncontrollable movements may also occur (RGG).

3. Ecstasy is a more or less extreme state of mono-ideism (ERE; ER; RGG) and may entail the cessation of the normally experienced flow of time as linear (RGG).

4. The ecstatic state raises the subject to a higher noetic sphere of consciousness than the common one and allows the subject insights into divine or religious truth, although they may remain inexpressible by way of normal, discursive language (ERE; ER; RGG; ODCC).

Furthermore, experience of levitation may also occur in connection with the ecstatic state (RGG); also the duration of the ecstasy may vary considerably (ERE; RGG).

The neurophysiological and psychological correlates that may possibly be related to the above mentioned manifestations of religious ecstasy I refer to the religio-psychological department for explication. ${ }^{6}$ I merely point out that the concept of "religious ecstasy" covers a host of phenomena for which it seems to function as a generic term and that, in the Sufi texts, it is one or several of these phenomena which should indicate the presence of religious ecstasy.

Not unexpectedly, since ecstasy evidently is related to universal categories of experience, $I$ have also come across reports of these phenomena in the Sufi texts. In the Sufi vocabulary there is even a rather differentiated terminology concerning these ecstatic experiences or states; whether different descriptions of one and the same experience are involved or whether the terms actually describe different experiences is a question that we must set aside for the present. There are, however, Sufis expressing the opinion that these different states of mind are based on one single experience in spite of the difference in terms (Al-Kalābādī ed. 1934, 96).

A generic term for these experiences or states is not to be found in the Sufi terminology however, so the problem of which of these phenomena must be present in order for ecstasy to be evidenced-or which of them

${ }^{6}$ In particular, the research findings detailed research should be observed in this context by Stanislav Grof in the account of his LSD- 
would be sufficient- does not therefore arise for the Sufis. So instead of speaking of religious ecstasy in general, they either refer to the single specific terms in question or else use the plural of one of the words employed to designate one of the terms we include in "religious ecstasy". They thus speak of "ecstasies", mawāğ -if one should at all attempt a translation of this plural. This plural is a genuine Sufi construction and does not otherwise seem to occur in the Arabic language, except as a later borrowing.

As-Sarrāğ (d. 988), author of the oldest known Sufi handbook, employs the plural mawāğìd a couple of times (As-Sarrāğ ed. 1963, 296 and 306) and so does al-Kalābādī a couple of years later (Al-Kalābādī ed. 1934, 99), but it is not-as far as I can see-until al-Qušayri about a hundred years later that the plural mawāğ $\bar{l} d$ receives a definition. "Mawāğ $\bar{l} d$,' he writes, "are the fruits of the litanies (tumrāt al-awräd)," respectively, he continues, "the results of 'clashes' (natā’iğ al-munāzalāt)" (Al-Qušayrī, ed. 1972-74, 217).

In the first definition of mawāğ $\bar{l} d$ as "the fruits of the litanies" al-Qušayri is most probably referring to the dikr-litanies, an assumption that is corroborated by a text from as-Sarrāğ that reads: "One day the forceful ecstasies [that occur] during the intensive $d i k r$-litanies (al-adkār al-qawìya) were mentioned in the presence of Sari as-Saqatī [...] 'Yes,' said Sarī, 'if his (the mystic's) face were hit by the sword he would not sense it' "' (AsSarrāğ ed. 1963, 306). Dikr we may briefly define as the act of calling God to remembrance verbally and/or mentally (bi'l-lisän/bi'l-qalb) through a prayer-formula or a formula of praise ( $d i k r$, pl. adkār or wird, pl. awrād); in Arabic, dikr can imply either the verb or the noun.

As to the second definition of mawăğid as "the results of the "clashes", the word "clash" here mirrors the fundamental Sufi view of the encounter between God and man as a highly dynamic one. This fundamental view runs through most definitions of the singular wağ $d$ which is usually translated by our "ecstasy". "Wağd," states al-Qušayrī, "is what your heart meets with and what comes upon you without [your] intention or [your] securing [it]', (Al-Qušayrī ed. 1972-74, 217).

In descriptions of this encounter, the following antithetical pairs of concepts are frequently recurrent: "closeness (qurb) / distance $\left(b u^{c} d\right)$ ", "presence (hudūr) / absence ( $\dot{g} a y b a)$ ", "attacking (huğüm) / vanishing (dahāb)", " "ecstasy (wağd) / loss [of ecstasy] (faqd)", "perplexity (dahša) / joyous rapture (tarab)", "drunkenness $(s u k r) /$ sobriety $(s a h w)$ ", " disappearence $($ fan $\vec{a})$ / staying $\left(\right.$ baq $\left.\bar{a}^{\prime}\right)$ ".

\footnotetext{
${ }^{7}$ So, for example, al-Hallāğ in his poem Mawāğ $\breve{i} d u$ haqqin (Al-Hallāğ ed. 1931, 54) as an early instance of this usage.
} 
Most of these words, also familiar from the general literature of Religionswissenschaft dealing with mysticism, are registered in the earliest Sufi manuals as technical terms, as for example in the above mentioned work by as-Sarrāğ (As-Sarrāğ ed. 1963, 333 sqq.), where they are described or defined in a way showing that they express phenomena within the ecstatic category of experience.

But instead of presenting these definitions and descriptions one by one and illustrating them with suitable anecdotal material-interesting and valuable as this might be-it now seems fitting to return to the little treatise $I$ mentioned at the beginning. The work concerned is a small tractate entitled Kitāb a ș-șafăa ${ }^{8}$ and attributed to al-Harrāz. Al-Harrāz died in 898 A.8D. and thus lived about a hundred years before as-Sarrāğ, author of one of the earliest Sufi manuals.

This short piece of writing is particularly interesting from two points of view, besides the history of its transmission-it has survived in only one known manuscript according to its editor (Al-Harrāz ed. 1967, 16): firstly, it is a quite rare original document demonstrating the presence of religious ecstasy in the world of Islamic spirituality; secondly, it is notable how the speaker in this text wrestles with the difficulties of expressing, through a literary medium, the experiences and states of mind that the ecstatic encounter with God has provided. Furthermore, this treatise also presents us with an exquisite sample of how the technical vocabulary of Islamic mysticism grows forth from an immediate personal experience, tentatively formulated in a literary form, out of which certain key-words have crystallized into so-called istiliahăt or technical terms; to enter upon problems connected with this process, however, would bring us too far afield.

This direct and unelaborated language, so characteristic of most firsthand reports of intensive personal experiences, also makes it difficult to provide an adequate translation, besides the purely formal deficiences of the text in question. I therefore ask for indulgence in respect to the translations to follow, as well as for possible misconceptions of the intended meaning of the original text, ${ }^{9}$ for I shall now let al-Harrāz speak mainly for himself for a while. I shall only complement his words with necessary explanations and commentaries and supplement them with the Arabic words that have later become incorporated into the standard Sufi vocabu-

${ }^{8}$ I read șafä with the editor of the text (Al-
Harrāz 1967, 22; cf. also the facsimile of the
title on page 25 of op. cit.), whereas Fuad
Sezgin reads sifät (Sezgin 1968,646 ) as does
Paul Nwyia (Nwyia 1970,252 ).
${ }^{9}$ I am very much indebted to the pioneer translation of this text by the late Paul Nwyia in his work Exégèse coranique et langage mystique (Nwyia 1970, 256-267) for my own translations from this primitive text. In some cases, however, I deviate from Nwyia's interpretations (cf., e.g., notes 11 and 15). 
lary concerning ecstatic experiences and states; it is of course beyond the scope and purpose of this essay to offer a requisite philological and contextual analysis of the writing in question, the aim of the present essay being primarily that of bringing one aspect of Sufi experience-the ecstatic -within the wider orbit of general religious experience and its psychology.

This treatise-which is formally constructed as a dialogue between alHarrāz and an anonymous seeker-commences with an account of four different ways of responding to God's calling. The first two concern that of the people of the world, the latter two that of the people of God. Let us immediately proceed to the response of the people of God.

While both categories belonging to the people of God choose God rather than the world-even to the extent that the latter is legitimate-yet the majority of those belonging to God miss the point of their choice because-according to al-Harräz-they are more occupied with the spiritual stations (maqāmāt) leading to God than with God himself. From those remaining unaffected by this spiritual gluttony, "God selects them for himself and shows them the greatness of His kingdom in order thereby to subject them to a veritable [spiritual] training, so that they can attack His majesty" (Al-Harrāz ed. 1967, 22).

The expression "attack His majesty" (al-huğüm 'alä "azmatihi) is not arbitrarily chosen by al-Harrāz but results from his reading of Sura 6:75 about Abraham. "Thus," this verse reads, "we (God) let Abraham behold the kingdom of the heavens and the earth in order that he should belong to the convinced ones." This verse al-Harrāz comments in the following way: "He let Abraham behold this in order that he might be able to attack God's nearness and His majesty" (Al-Harrāz ed. 1967, 22). ${ }^{10}$

"Attack God's nearness"- -with these words al-Harrāz clearly declares the Sufi point of departure for the encounter with God as a spiritual combat on the part of the mystic. We thus find here a fairly early attempt at the definition of mawāğ $\breve{l} d$-ecstasies-subsequently given by al-Qušayrī as "the results of the "clashes'" (cf. supra p. 154).

It is worth while noting that al-Harräz' use of the rather strong verb "attack" (huğüm)-with its primary association of a hostile and capricious assault-in order to illustrate the active encounter of the mystic with God already occurs in the earliest Sufi handbooks as a technical term but in a weaker and more passive sense (As-Sarrāğ ed. 1963, 341 and Al-Qušayrī ed.

${ }^{10}$ This exegesis by al-Harrāz is also literally rendered in as-Sulami's (d. 1022) collection of Sufi Koran commentaries, his $\mathrm{Haq}^{3}$ iq attafsìr, (Ms. Br. Lib. Or. 9433, fol. 62 a); this

circumstance may thus also serve as indirect proof of the genuineness of the authorship of the tractate in question. 
1972-74, 251, where its definition is almost synonymous with that of wağd translated above on page 154). In addition, the object of the "attack"nearness (qurb) - has become part of the standard Sufi terminology (AlKalābādī ed. 1934, 77).

Admonished by his anonymous interlocutor, al-Harrāz now sets out to describe the first spiritual station characteristic of those possessing the spiritual stations of nearness to God, and he begins with: wağd-ecstasy! The first stage of wa gld he describes as "concentration of intention (hamm) by way of intensive [self-]observation (muräqaba), calmness of the limbs through rest, drawing close to God together with little variation in the notions of contemplation (hatarāt al-mušăhada), and with few movements when experiencing the first flashings of the ascending [sun-]light (bi' $d a w q$ țawàli al-muțāla a) ${ }^{11}{ }^{11}$ fleeing into solitude ( uzla), separation (infirād), and loneliness (wahda) [...] and seeking rest with Him after the confusion and the multitude of means [employed] in the search of obtainment, and becoming happy with Him and finding intimacy with His word [from Sura 7: 157] 'He lifted their burden from them' [...]' (Al-Harrāz ed. 1967, 23).

From a psychological point of view, one phrase above all in this description might arouse particular interest, viz. "when experiencing the first flashings of the ascending [sun-] light". The expression "first flashings" $(t a w \bar{a} l i)$ is listed in the technical vocabulary of the Sufis and it will thus be profitable to turn directly to as-Sarrāğ for illumination of this term. "The first flashings (at-tawāli)," he explains, "are the lights of the realization of God's unconditional unity (anwär at-tawhìd) which shine on the hearts of the gnostics (al-'ärifün) through their radiation and which through the power of their brightness calm what there is of light in the hearts, just like the ascending sun. When she has arisen, the brightness of the stars disappears from the onlookers as a result of the power of the sun's light in spite of the stars remaining in their places" (As-Sarrāğ ed. 1963, 345).

But al-Harrāz' friend is not content with this and asks him to describe a spiritual station even better than this first one, so al-Harrāz proceeds to the description of the next spiritual station as: "Stupefaction (dahra) from the ominous impressions ( $t a w \bar{a} r i q$ ) of awe, and bewilderment from continuous exaltation [of God]; as a sincere yearning and as a contentment due to purity of union (ittișâl), as a consumption of much food without greed as a

${ }^{11}$ The original reads islbol 5 j بهلو (Al-Harrāz ed. 1967, 23) but in order to obtain a meaningful rendering I suggest we read as as a cor- rection of an unhappy reversal of order. Nwyia, however, follows the original reading in this case and translates with: "[ . . . ni trop se laisser mouvoir par les premiers éclairs de la connaissance gustative" (Nwyia 1970, 259). 
result of being passionately in love, and as an overwhelming wisdom. Most strong gnostics ( ${ }^{a} \bar{a}$ rifüun), when experiencing the realities of nearness, start screaming and become stupefied, for they become wild [when they realize] that $\mathrm{He}$ is looking at them in various ways until $\mathrm{He}$ lets $\mathrm{His}$ veil fall over them and shades them in His bosom and lets them enter behind curtains illuminated with His light [.. .] From here they return with splendid marks of honour, not knowing what they have arrived at, for they are stupefied in this spiritual station. When they awaken from their stupefaction they become perplexed over what they have arrived at with [God's] permission; but what they conceal is greater yet" (Al-Harrāz ed. 1967, 23).

After this informative report, in which most of the criteria of ecstasy offered by Religionswissenschaft are easily recognizable, al-Harrāz offers an account, no less interesting from the psychologial point of view, about the ecstatic's situation after returning from his ecstatic state.

"You should know," al-Harrāz confides in his friend, "that most of the weeping of the aspirants, their confusion, their screaming, and their movements are the result of grief following upon the spiritual stations [they have experienced] [...] And these in their turn are the result of the ascending lights [of the spiritual sun] ( $m u t \bar{a} l a^{c} \bar{a} t$ ) due to nearness [to God], for they have beheld Him whom they have not [previously] beheld and they have heard the speech of God Most High that has not [hitherto] been their nourishment. This overwhelms them, for in spite of themselves these ideas (hatarāt) come upon them. And when that comes upon them of which they but seldom have had experience, this astonishes them, and that becomes manifest in them which you [can] see [yourself]. Those who are strong in gnosis (ma rifa) are not affected by this state of mind however" (Al-Harrāz ed. 1967, 24).

The rather surprising expression in the previous description of the second spiritual station of nearness to God as, inter alia, "the consumption of much food without greed as a result of being passionately in love" (cf. above), here receives its explanation in the fact that it is now the immediate listening to the word of God Most High that constitutes the main nourishment of the mystic.

At the request of his friend, al-Ḧarrāz now brings him yet deeper into the secrets of nearness to God and makes it clear to him that there now is no further spiritual station to follow but that an intensification of the station in which the ecstatic already dwells takes place, which results in "the forgetting of the lot allotted him by God and the forgetting of his needs with regard to God; God's nearness has cut the mystic off from [his] calling God to remembrance ( $d i k r$ Alla $h$ ): he $i s$ now with God and needs no longer call Him to remembrance, and he no longer finds [his own] understanding 
$(f a h m)$ interceding between God and him. The attack upon God (al-huğüm 'ala Allāh) has freed him from [the consciousness of] having found God: the slave [of God] becomes abolished (saqata) ${ }^{12}$ and God [alone] remains (baqiya)" (Al-Harrāz ed. 1967, 24)!

Al-Harrāz now experiences the agony of not finding adequate words for communicating what he has undergone and concludes this passage with: "All that I have mentioned to you is different from what I wanted to mention and I do not recognize it and I do not know what I want and I do not know what I say and I do not know who I am or from where I am. You who listen, do you understand what I say? It is a slave who has lost his name and no longer has a name, he is ignorant and no longer possesses any knowledge-but yet he has knowledge and yet he is not ignorant [...] Oh, how I long for one who recognizes what I say and together with me enters into what I say"' (Al-Hुarrāz ed. 1967, 24)!

For the last time al-Harrāz's friend insists on also having the ecstasy of this intensified spiritual station described. And as invaluable help in our understanding of the ecstatic experience of the Sufis, al-Harrãz agrees to this and announces that "he who has been drawn close [to God] (muqar$r a b)^{13}$ is in reality as if under supervision: he is sought and suspended, without knowledge, understanding, will, sensation, or movement. He is the happiest of creatures, except that those realities of the ecstatic state that are [still] valid for him in his realization of God's unconditional unity (haq $\bar{a}^{\prime} i q$ al-wuğ $\bar{u} d$ lahü fi't-tawhhid) come between him and [the final] happiness. His spiritual station consists of a joyous rapture (tarab) due to continuous beholding of Him, and if it is said to one of those [in this station] 'What do you want?' he answers 'God'. If it is said to one of them 'What is your knowledge?' he answers 'God'. And if his limbs could talk they would say 'God'. For his members, his joints, and his limbs are filled with the light of God. He knows nothing but God and all his knowledge is from God, yes, he himself is from God, through God, unto God, and with God. His identity and his reckoning have vanished (dahaba) ${ }^{14}$ If one says to him 'What are you?' he would be unable to answer ' $I$ ', because of the preponderance of God's decrees. This is the reality of their ecstasy. And when he reaches the peak of nearness, he cannot even say 'God' " (Al-Harrāz ed. 1967, 24-26). This definitive ineffability occurs, al-Harrāz reveals to us, when also the

12 It is interesting to notice how al-Harrāz,
known in the Sufi tradition for having been
the first to talk about fan $\bar{a}^{\prime}$ (and baqa') (Su-
lami ed. 1953, 228), not once in this dialogue
uses the term fana $\bar{a}$ but prefers synonyms
thereof such as saqata or dahaba in order to express the underlying experience which has later become conceptualized through the notion of $\operatorname{fan} \bar{a}^{\text {. }}$.

13 According to Nwyia, al-muqarrab alludes to al-muqarrabūn in Sura 56:11 and 88 .

$14 \mathrm{Cf}$. note 12 . 
gnosis [-consciousness] (maiarifa) has left (dahaba) the mystic (Al-Harrāz ed. 1967, 26).

After this description of ecstasy, in which we continue to recognize without difficulty most of the criteria of ecstasy that $I$ reported at the beginning (cf. supra p. $227 \mathrm{f}$.), al-Harrāz resumes his previous, highly interesting description of the ecstatic's situation after the cessation of his ecstasy.

"You should know," al-Harrāz imparts to his friend, "that a life in perfection does not apply to the gnostics and that they are not completely delighted in this station, for after the presence [with God] they are [spiritually] absent even if they are [corporally] present [...] They are without [spiritual] aspiration (himma), without purpose, without means, without claim, without flight [into solitude (?)], without ecstasy (wağd) and without loss [of ecstasy] (faqd) [...] they see His reign as perfect as well as His remembrance $(d i k r)$ of them as perfect in all matters $\mathrm{He}$ has willed [for them]. Their lot from Him is perfect and what is with Him is perfect before they were [born] and after they were [born]. So is His purpose with them and for them perfect. Their calling Him to remembrance ( $\underline{d i k r}$ ) does not add to their nearness to Him, nor does their negligence ( $\dot{g} a f l a)$ [in calling Him to remembrance] subtract for them from what was [decreed] for them with Him [...]'" (Al-Harrāz ed. 1967, 27).

The reality behind this existential suspension and spiritual impotence is the circumstance that the mystic's act of calling God to remembrance ( $d i k r$ ) during the ecstatic realization of God's unconditional unity (tawhid) has become assimilated with the absolute theomnemy ( $d i k r)$ of God's primordial calling to remembrance of His creation, in which no trace of the mystic's own activity remains but only God's acting through the mystic. Al-Harrāz formulates this total monoideization in the words: "God calls himself to remembrance through his (the mystic's) person (nafs) when $\mathrm{He}$ so desires, He praises himself through his tongue when He desires, and $\mathrm{He}$ glorifies himself through his laudations [...] So what place is there for 'I' or for 'You', ' (Al-Harrāz ed. 1967, 27)? ${ }^{15}$

15 That is, the ordinary references of identity have become void of meaning. I deviate here from Nwyia's translation which reads: " [. . . Il fit mémoire de Lui-même par Luimême, quand Il le voulut; [. . . II Se louangea par Sa propre langue, quand Il le voulut; [ . . ] Il Se glorifía de Ses mérites dans l'exercice de Sa propre puissance. Où étions-nous, toi et moi" (Nwyia 1970, 265)? The original reads (Al-Harrāz ed. 1967, 27):

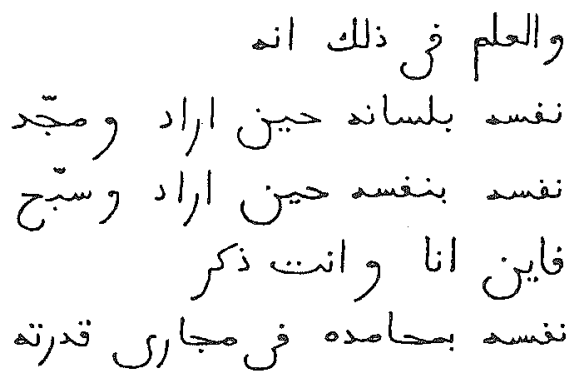


The condition for the mystic's realization of God's unconditional unity (tawhìd) thus consists in a complete forgetting of ' $\mathrm{I}$ ' and thence of 'You', which al-Bisțāmī, who died a quarter of a century before al-Hुarrāz, has expressed in the following words: "Upon the forgetting of one's person, the Creator's calling the person to remembrance follows ( inda nisyän an-nafs dikr bāri' an-nafs)" (As-Sahlağì ed. 1976, 105).

The Sufis, with their well-developed sense for the conditions of the spiritual life, have captured this psychological dialectic between the calling of God to remembrance ( $d i k r)$ and the forgetting of self (nisyān) in a very eloquent paradox as in the following quotation from al-Wāsiți (d. 932): "Those who remember [their act of calling God to remembrance] during their calling God to remembrance are more negligent than those who are forgetful [of their act of calling God to remembrance] during their calling God to remembrance for [the act of] calling Him to remembrance is other than He" (As-Sulamī ed. 1953, 305). ${ }^{16}$

That ecstasy has been a conducive factor for this forgetting of self is obvious. Al-A rābī (d. 952), whose work on ecstasy as-Sarrāğ has preserved in a summary, was, for instance, quite aware of this, for he writes: "Ecstasy in this world does not consist of the full disclosure [of God] but [is] the heart's contemplation (mušāhada) [...] He (the mystic) contemplates [God during ecstasy] out of joy of certitude and purity of theomnemy (dikr), for [during ecstasy] he is quite alert [inwardly] (muntabih)" (AsSarrāğ ed. 1963, 311).

Lest we ourselves fall victims to spiritual gluttony in trying to examine the nature of the theomnemy which-according to al-Harrāz- "makes the heart beat from calling God to remembrance, makes the tongue mute, and the value of which nobody knows but God Most High" ('Atțarr ed. 1961, II 38), we shall content ourselves with what al-Harrãz has let us know about the experiences of the Sufi ecstatic. Besides, we have most certainly got to know more about the workings of ecstasy and the secrets of nearness to God than what was intended for the outsider. In a book about the external aspects of intimacy with God, al-Hुarrāz has stated unequivocally "that

I do not think that bi'nafsihi, bi'lisānihi, and bi'mahämidihi should be interpreted as reflexive, an opinion that is confirmed by the following quotation attributed to al-Bisțāmi (As-Sahlağì ed. 1976, 105):
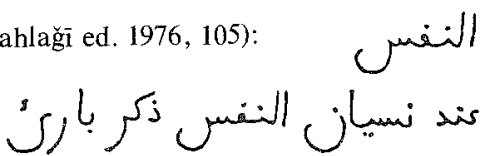

${ }^{16}$ The point of the paradox is, of course, that an awareness of one's own activity of calling God to remembrance during theomnemy distracts the person from perceiving God's antecedent remembrance of him, whereas he who has an undivided awareness of God's primordial remembrance of him and forgets his own activity of calling God to remembrance, perhaps even the external act of calling, during theomnemy has a greater chance of so doing. 
what remains of the spiritual stations of intimacy with God is more and weightier than can be put forward in a book; but something may be obtained in discourse with those who know about it' (Al-Harrāz ed. 1975, 73). And discourse with such a person we have been lucky enough to follow!

With regard to one side of the Sufis' ecstasy, al-Harrăz leaves us behind, namely the question whether their ecstasy was spontaneously generated and hence not intentionally induced or whether the Sufi at this time had recourse to expedients for the express purpose of inducing ecstasy-and in that case, which ones.

However, just as we are not over-indulged with first-hand material about the internal dimensions of ecstasy- "for he who asks how good God tastes asks the impossible, for this cannot be perceived through description but only by him who has gotten to taste [and see]"' (al- Á rābī, ap. As-Sarrāğ ed. 1963, 313)-likewise we are not over-indulged with first-hand sources about the external dimensions of ecstasy either. This situation holds true at least for the period before the consolidation of the orders (sg. tariqa) and their monopolization of the spiritual life, i.e., before the thirteenth century when the ecstasy-inducive rituals we usually associate with this context,

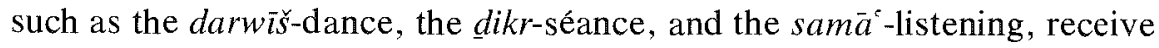
their definitive structures and breakthrough.

And since there now is no al-Harrāz to succour us, we must instead try to shape a picture for ourselves from those disparate notices that are available concerning the external conditions of ecstasy. That the Sufis did employ existent liturgical resources in order to attain an ecstatic state of mind becomes admirably clear from a previously quoted passage (cf. supra p. 229) from as-Sarrāğ's Kitāb al-lumac, where the commentary is reproduced which Sarī as-Saqatī (d. 865) gave when he was told of "those forceful ecstasies [that occur] during the intensive dikr-litanies and there-with related phenomena that influence the mystic [...]"' (As-Sarrāğ ed. 1963, 306).

In another passage as-Sarrāğ confirms this circumstance in his own words: "You should know," he writes, "that absence/presence (gaybal $h u d \bar{u} r$ ), sobriety/drunkenness (sahw/sukr), ecstasy (wăgd), attacking (hu$\breve{g} \bar{u} m$ ) and overwhelmings ( $g a l a b \bar{a} t)$, disappearence/staying (fan $\left.\bar{a}^{\prime} / b a q \bar{a}^{\prime}\right)$ belong to those states that have been actualized through theomnemy (dikr) and exaltation ( $t a$ 'zim) of God"' (As-Sarrāğ ed. 1963, 344).

In addition to this, as-Sarrāğ claims that in the traditions ( $a h b \bar{a} r$ ) there are many reports about those who "heard a word (kalima), a dikr-litany (dikr), an edifying speech (maw'aza), or a fine wisdom-word ( $h i k m a)$ that gladdened them and elicited ecstasy (wa ğd) in their inmost (sirr) ..." (AsSarrāğ ed. 1963, 295). 
Now we also know that there have existed, from the middle of the eighth century, so-called $\underline{d i k r}$-sessions (mağălis ad-dikr or halaq ad-dikr), in which various $d i k r$-litanies were recited, chosen Koran-words were proclaimed and edifying speech was listened to (cf. Massignon 1968, 105). Although it is not possible to enter into details here, it is in all probability this liturgical milieu, with or without connection to the ordinary divine service, that constitutes the historical background of the subsequent traditional dikrséance and samāe-listening.

Unfortunately, the material at our disposal does not allow us any possibility of judging to what extent the Sufis have purposely utilized these liturgical resources in order to put themselves in an ecstatic frame of mind, or how these gatherings were organized or structured. It was probably not until the so-called educating shaykh ( $\check{s} a y h$ at-tarbiya) in the eleventh century that these sessions, as far as the Sufis are concerned, received their definitive organization and guidance.

We do know, however, that there were individual Sufis who tried to imitate the ecstatic state and who behaved as if they were in ecstasy (tawăğada) —a feigned ecstasy may also be conducive to real ecstasy. But this is more specifically a Sufi problem proper, concerning genuine and false ecstasy according to their own criteria of judging ecstasy and, in the last instance, a problem which only they themselves are qualified to settle.

In any case, Louis Massignon's statement remains irrefutable: "A fact to be borne in mind," he writes, "is that psalmody based on the Koranic vocabulary remains the main procedure for putting oneself in ecstasy." (Massignon 1968, 106) If we add 'and listening to psalmody', we then obtain a fairly satisfactory picture of the external conditions for the Sufis' ecstasy until the eleventh century, when various innovations begin to appear (Massignon 1968, 106). And as far as the darwǐ̌s-dance is concerned, it is not until the thirteenth century with Rūmī (d. 1273) that it becomes transformed from an expression of ecstasy-and as such, quite a controversial one (Molé 1963, 147)_into an expedient for ecstasy (Meier 1954, 127). Stimulants such as hashish, coffein, and opium also seem to have been first introduced during the thirteenth century (Massignon 1968, 107).

To illustrate the external conditions of ecstasy I would like to relate, by way of conclusion, firstly the case of at-Tustarī, a contemporary of alHarrāz, a case which illustrates both the liturgical context of ecstasy and some of its concrete manifestations; and secondly the case of al-Ğunayd, also a contemporary of al-Harrāz, a case which illustrates spontaneously generated ecstasy.

First, at-Tustarī (d. 896): "It is reported that when Sahl at-Tustarì listened to a $\operatorname{samă}^{c}$ (a kind of musical performance), ecstasy (wăgd) manifest- 
ed itself in him. For twenty-five days he remained in this ecstasy and ate no food. And in spite of it being winter, he sweated to the extent that his shirt became wet. When he was in this state, learned men put questions to him, and he answered 'Do not ask me since a word from me at this point of time is not meaningful to you" ('Atțār ed. 1961, I 230)!

And finally al-Ğunayd (d. 910): "Ğunayd put a question to Šiblī and said 'What about your theomnemy (dikr)? You do not heed the true theomnemy, do you?' Siblì replied 'It is inessential how many times I call Him to remembrance, if He just calls me to remembrance one single time!' At these words, Gunayd fell into ecstasy (literally: came out of himself-az hod bešod)" ( Aț̣ār ed. 1961, II 148).

\section{References}

Anawati, G.-C.-Gardet, L. 1960. Mystique musulmane. Paris.

Andræ, T. $1980 .^{2}$ Islamische Mystik. Stuttgart.

- 1981. I myrtenträdgården. Lund.

Arbman, E. 1968. Ecstasy or religious trance in the experience of the ecstatics and from the psychological point of view 2: Essence and forms of ecstasy. Stockholm.

'Aț̣ār, Farīd ud-Dın, ed. 1961. Tadkirat ul-awliyā', I-II, edited by M. M. Qazvīnī. Tehran 1339 š.

DCR 1970. A Dictionary of comparative religion, ed. by S. G. F. Brandon. New York.

DS 1961. Dictionnaire de spiritualité, ed. by M. Viller et al. 4. Paris.

ER 1945. An Encyclopaedia of religion, ed. by V. Ferm. New York.

ERE 1912. Encyclopaedia of religion and ethics, ed. by J. Hastings 5. Edinburgh.

Gardet, L. 1950. Quelques textes șüfis concernant 1"'extase"'. Revue thomiste 50.

- 1961. Extase dans la mystique musulmane. Dictionnaire de spiritualité 4, 2068-2072. Paris.

Grof, S. 1976. Realms of the human unconscious. New York.

Al-Hallāğ, Husayn ibn Manșūr. ed. 1931. Le dīwān d'al-Hallāj, essai de reconstitution, édition et traduction, par L. Massignon. Journal asiatique 218.

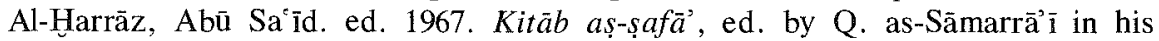
Ras $\bar{a}^{2}$-il al-Harrāz. Baghdad. (This edition also printed in Al-Mağmac al irāqī. Mağalla 15. Baghdad 1967.)

— ed. 1975. Kitāb as-șidq, ed. by 'Abd al-Halīm Maḥmūd. Cairo.

Al-Kàābādī, Abū Bakr Muhammad ibn Ishạā. ed. 1934. Kitāb at- táa arruf li'madhab ahl at-tașawwuf, ed. by A. J. Arberry. Cairo.

Massignon, L. 1968.2 Essai sur les origines du lexique technique de la mystique musulmane. Paris.

Meier, F. 1954. Der Derwischtanz. Asiatische Studien 8.

- 1971. Hurāsān und das Ende der klassischen Șūfik. La Persia nel medioevo. Rome.

Molé, M. 1963. La danse extatique en Islam. Sources orientales 6.

Nwyia, P. 1970. Exégèse coranique et langage mystique. Beyrouth. 
ODCC 1958. The Oxford dictionary of the christian church, ed. by F. L. Cross. London.

Ornstein, R. E. 1977. The psychology of consciousness. New York.

Al-Qušayrī, Abu'l-Qāsim. ed. 1972-74. Ar-Risälat al-qušayrīya, ed. by 'Abd alHalīm Mahmūd and Muhammad ibn Śarif. Cairo.

RGG 1958. Die Religion in Geschichte und Gegenwart, ed. by K. Galling 2. Tübingen.

As-Sahlağ̄i, Muhammad ibn 'Alī. ed. 1976. ${ }^{2}$ An-nūr min kalimāt Abì Tayfūr, ed. by 'Abd ar-Raḥmān Badawī in his Šatahāt aș-șūflya 1. Kuwayt.

As-Sarrāğ, Abū Nașr. ed. 1963. ${ }^{2}$ Kitāb al-lumá fít-taṣawwuf, ed. by R. A. Nicholson. London.

Sezgin, F. 1968. Geschichte des arabischen Schrifttums 1. Leyden.

As-Sulamī, Abū 'Abd ar-Raḥmān. Ms. Br. Lib. Or. 9433. Haqā̉ iq at-tafsīr. (British Library Oriental Manuscripts no. 9433.) London.

- ed. 1953. Tabaqāt aṣ-șūfìya, ed. by Nūr ad-Dīn Šurayba. Cairo. 